\title{
GONDOLATOK AZ EGYSÉGES TANÁRKÉPZÉS TÖRTÉNETÉBŐL
}

\section{KARDOS JóZSEF}

\author{
az ELTE Bölcsészettudományi Karának \\ professor emeritusa \\ kardos.jozsef@btk.elte.hu
}

\begin{abstract}
Az 1945 utáni oktatástörténet többször visszatérö problémájának, a pedagógusképzésneks ezen belül az egységes tanárképzés alakulásának sajátosságait, fó állomásait tekinti át a tanulmány. Bemutatja azokat a politikai és állami dokumentumokat, amelyek meghatározták a pedagógusképzés alakulását, ezzel párhuzamosan képet ad a politika és az oktatásirányítás kapcsolatáról, a közvetlen pártirányításról, a helyi érdekek szerepéröl.
\end{abstract}

A kötelező nyolcosztályos iskola tanárképzési igényei, megoldáskeresések

Az 1945 utáni oktatástörténet vissza-visszatérő problémája volt a pedagógusképzés, ezen belül az egységes tanárképzés kérdésköre. Ez utóbbi esetében a kiindulópontot az 1945 őszén létrehozott általános iskola adta.

A minden gyermek számára kötelező nyolcosztályos iskolában a felső tagozatos diákok számára szakrendszerü oktatást kívántak biztosítani. Ez azonban rövidtávon megoldhatatlannak bizonyult, hiszen szaktanárok csak a polgári iskolákban és a gimnáziumokban voltak. Az általános iskola létrejöttével a 10-14 éves korosztály tanulási igénye a felső tagozaton rohamosan nőtt. 1945-ben 160 ezer tanuló került ki ebből a korosztályból, ez a szám 1947-re 624 ezerre emelkedett. Számukra kellett szaktanárokat biztosítani.

Először egy gyors, de szakmailag igénytelen megoldáshoz folyamodtak; ,,gyorstalpaló" tanfolyami átképzésre gondoltak. 1947. július 3-án Ortutay Gyula vallásés közoktatásügyi miniszter előterjesztést készített a minisztertanács számára. Ebben igen szakszerüen fogalmazott: „Az általános iskola kifejlesztésének egyik legfontosabb feltétele az, hogy ebben az új iskolafajtában megfelelő szakképzéssel rendelkező nevelők müködjenek." (Lásd: A vallás- és közoktatásügyi miniszter előterjesztése, id. Kardos és Kornidesz, 1990, 110-111. o.) A megoldási javaslat azonban elszomorítóan színvonaltalan volt: tanítókat kívántak szakmacsoportok szerint átképezni néhány hét alatt. Az ennek alapján 1947. július 17-én elfogadott kormányrendelet (8930/1947.) kimondta, hogy „lehetővé kell tenni az általános iskolában tanító tanítók számára a szakrendszerü tanításra való képesítés megszerzését." Ennek érdekében két nyáron át hat-hat hetes, bentlakásos tanfolyamot kell szervezni, ahol felkészítik a tanítókat a szakmacsoportos tanításra (szakmacsoport 
például: magyar, történelem, földrajz stb.). A résztvevőknek vizsgát kell tenniük, amely képesíti őket a választott szakmacsoport tárgyainak oktatására az általános iskolában.

Az átképző tanfolyam szerencsére csak a korszellemet tükröző terv maradt. A megoldás pedagógiai föiskolák létesítésével született meg. 1947-ben Budapesten és Szegeden, 1948-ban Debrecenben és Pécsett indult a képzés. Debrecenből 1949-ben Egerbe telepítették át a föiskolát, Budapesten 1955-ben megszüntették, de 1976ban Csepelen újraindult a képzés. Nyíregyházán 1962-ben, Szombathelyen 1971-ben alakult föiskola. Az alapításnál is nagyobb gondot jelentett, hogy a változó iskolai igények következtében hektikusan alakult a képzési idő és a felveendő szakok száma is: 1947-1950 között a képzési idő három év, a szakok száma kettő-három-négy; 1950-1954 között a képzési idő két év, a szakok száma egyre csökkent. 1954-1959 között a képzési idő ismét három év, a szakok száma pedig kettő; majd 1959-1964 között négy évessé és három szakossá válik a föiskola. 1964-töl vezetik be a négy éves képzési időt és a két szakot. Ettől kezdve egyre kiegyensúlyozottabbá válik az oktatás.

A képzési időnek és a felveendő szakok számának viszonylag gyors változása ártott a képzés színvonalának. Akárcsak a főiskolák oktatóinak összetétele és igen változó szintü felkészültsége. Mindez rontotta a föiskolák elismertségét, annak ellenére, hogy kiváló nevelők is oktattak ezekben az intézményekben. Akik az egyetemi szintủ egységes tanárképzést javasolták, gyakran hivatkoztak a minőség emelésének igényére.

1954-ben állt elő az oktatásügyi kormányzat egy javaslattal, ami - véleményük szerint - segíthetne a kialakult helyzeten. Nem a pedagógusképző föiskola fejlesztését tüzték ki célul, hanem olyan egységes tanárképzést, amely a pedagógusképző főiskolák adminisztratív felszámolását jelentette volna. Az igazi mozgatóerő a hivatkozáshoz felhasznált minőségemelésen túl a pedagógusképzésben, elsősorban az egyetemi szintủ tanárképzésben mutatkozó rendkívüli túlképzés volt. A tervezés 1950-1953 között arra alapozott, hogy a középfokú oktatás az iskolák, az osztálytermek száma fokozott mértékben fog növekedni. 1953 után kiderült, hogy erre az adott körülmények között nincs lehetőség. Így már 1954 nyarára olyan helyzet állt elö, ami nagy gondot jelentett a középiskolai tanárok elhelyezésénél: 749-en végeztek, de a szükséglet csak 349 volt. A további számítások szerint 1957-ig 3370 fö végzősből csak 415-re lett volna szükség.

Ezek a feszítő gondok hozták elő, tüzték napirendre az egységes tanárképzés elképzelését, amely szerint az általános iskolai és középiskolai szaktanárok képzését a tudományegyetemek keretén belül egyesitik, és a négy pedagógiai föiskolát megszüntetik. Ugyanakkor a tudományegyetemek bölcsész- és természettudományi karain a nem tanári szakképzésről külön gondoskodnak. Az Oktatásügyi Minisztérium (OM) erről 1954 márciusában a Politikai Bizottság számára előterjesztést készített. Ebben hangsúlyosan szóltak arról, hogy a föiskolákon végzett tanárok szak- 
tudása rendkívül hiányos. Ugyanakkor elismerték, hogy a pedagógiai főiskolák aránylag jó pedagógiai és módszertani kiképzést adnak. Ezzel szemben az egyetemeken folyó tanárképzés lényegesen jobb szaktudás biztosít, de elhanyagolják a pedagógiai és a módszertani felkészítést. Az egyetemi szintủ egységes pedagógusképzés a kölcsönös előnyöket egyesíthetné. Ezért már 1954 öszétől a minisztérium a tudományegyetemeken kívánja megoldani a középiskolai és az általános iskolai (felső tagozatos) tanárok képzését. Ezt a három múködő tudományegyetem - mint írták -, biztosítani tudja. Javasolták továbbá az MDP Politikai Bizottságának, hogy a tudományegyetemek bölcsészettudományi karain is válasszák szét a tanárképzést és a szakképzést.

Az előterjesztés a gyors intézkedéshez gyakorlati javaslatokat is kínált: főiskolai tanárok elhelyezése, épületek felhasználása stb. (Lásd: Az Oktatásügyi Minisztérium javaslata, id. Kardos és Kornidesz, 1990, 191-196. o.)

Az MDP KV agitációs és propaganda osztálya a minisztériumi javaslattal szemben meglehetősen éles ellenvetésekkel élt. Az Oktatási Minisztériumot hibáztatta amiatt, hogy 1945 óta a tanítóképzők és a pedagógiai föiskolák sorozatos átszervezést szenvedtek el. Az OM munkájára - írta a pártjelentés - a prakticizmus, a reformok túlhajtása, a tudományos tervezés teljes hiánya a jellemző. Állítják, hogy az előterjesztés adatai is pontatlanok. Például az áll benne, hogy 1957-ig 4598 középiskolai tanár végez, ezzel szemben az OM csak 3370 tanárral számol. Az OM a kialakult helyzetből csak egyetlen kivezető utat javasol: az egységes tanárképzés bevezetését. Ugyanakkor figyelmen kívül hagyja az óvó- és tanítóképzés gondjait. Arról sem szól, hogy az egyetemek az adott pillanatban lényegében 80 százalékban az általános iskolák felső tagozata számára képeznek nevelöket.

Az agit. prop. osztály szerint az egységes tanárképzésre való áttérés tovább növeli az alsó és a felső tagozat közötti szakadékot, melyet sem szakmailag, sem pedagógiailag nem tartanak indokolhatónak. Az OM a javasolt reformra szokás szerint rendkívül rövid határidőt adott. 1954 szeptemberére kívánták bevezetni az egységes tanárképzést. Ezt a határidőt a pártjelentés komolytalannak minősítette. Azt is elítélték, hogy a minisztérium szakmai fórumokkal nem vitatta meg elképzelését.

Mindezek alapján azt javasolták, hogy a Politikai Bizottság ne foglaljon állást az egységes tanárképzés ügyében, hanem szólítsa fel az Oktatási Minisztériumot, hogy fél éven belül a pedagógusképzés egész helyzetéröl tegyen jelentést a Politikai Bizottságnak. (Lásd: Az MDP KV agitációs és propaganda osztályának kiegészítő javaslata..., id. Kardos és Kornidesz, 1990, 197-201. o.) Az MDP KV agitációs és propaganda osztályának érveit elfogadva a Politika Bizottság az egységes tanárképzésre vonatkozó OM javaslatot 1954. március 10-én hozott határozatával elutasította.

A PB az MDP KV agitációs és propaganda osztályának, az Oktatási Minisztériumnak, a Pedagógus Szakszervezetnek és az Országos Tervhivatalnak a részvételével egy bizottságot küldött ki, amelyet meglehetősen általános feladattal bízott 
meg: vizsgálják meg „oktatási rendszerünk egész kérdését és dolgozzák ki mindazokat a rendszabályokat, melyek szükségesek a hiányosságok megszüntetése érdekében." (Lásd: Az MDP Politikai Bizottságának..., id. Kardos és Kornidesz, 1990, 202. o. ${ }^{1}$ )

A kiküldött bizottság javaslatai alapján az MDP Központi Vezetősége 1954. július 23-án határozatot hozott a „pedagógusképzés egyes kérdéseiről”. Kimondták, hogy a középiskolai tanárképzés ideje négy esztendő maradjon, az általános iskolai tanárképzést pedig három évre kell emelni. Tehát nincs szó egységes tanárképzésről, de a túlképzés miatt javasolták, hogy egy pedagógiai föiskolát szüntessenek meg. A Központi Vezetőség helytelenítette, hogy három évvel korábban egyszakos képzést vezettek be az egyetemi tanárképzésben, mert állították, hogy ez a gyakorlatban nem vált be. Ezért vissza kell térni a kétszakos képzésre. (Lásd: Az MDP Központi Vezetőségének határozata..., id. Kardos és Kornidesz, 1990, 204-205. o.)

A határozat nyomán - ami ékes bizonyítéka volt a közvetlen pártirányításnak a Minisztertanács 1017/1955. számú határozatával megszüntette a Budapesti Pedagógiai Főiskolát. A döntés közel két millió forint megtakarítást jelentett, de a fővárosi általános iskolákban hamarosan súlyos szaktanár-hiány támadt. Ezt nehezen lehetett vidéki tanárokkal megoldani, mert a túlzsúfoltnak mondott Budapesten tiltották a letelepedést. Ezért kellett az 1970-es évek közepén létrehozni Csepelen - egy általános iskola épületében - az Egri Tanárképző Főiskola kihelyezett tagozatát. (Új főiskola létesítését a pártvezetés nem engedélyezte.)

\section{Eltérő érdekek, befolyások és elképzelések az egységes tanárképzés kapcsán}

1957 nyarán a Mủvelődésügyi Minisztériumban a Felsőoktatási Főosztály javaslatot tett az egységes tanárképzés bevezetésére. Indokaik között szerepelt, hogy főiskolai szinten a „tudományos szintü oktatás személyi feltételei általában nincsenek biztosítva." Az egyetemeken végzett középiskolai tanárok 80 százaléka került 1955-56 között áltanos iskolákba. Tehát az egyetemi képzés erre a szintre is irányul. „Jelenleg - írta az előterjesztés - a pedagógiai főiskolák lényegesen kevesebb tanárt adnak évente az általános iskoláknak, mint az egyetemek." Új helyzetet teremt - állították -, hogy az óvó- és tanítóképzés 1959-től felsőfokúvá válik és két éves lesz. A föiskolai tanárképzés csak három év, az egyetemi pedig öt esztendő. „Mindebből következik - írták az előterjesztők -, hogy az egyetemek keretében át kell térni az egységes tanárképzésre. Ez a képzési rendszer emeli az általános iskolai tanárok szakmai színvonalát, egyensúlyt teremt a pedagógusképzés rendszeré-

\footnotetext{
${ }^{1}$ A magyar Országos Levéltárban csak a minisztériumi előterjesztés található, MOL 276. f. 53. cs. 164. ö. e., a politikai bizottsági vita, a határozat nem. Lehet, hogy az MDP PB vita nélkül fogadta el az agitációs és propaganda osztály javaslatát. A PB határozat a Párttörténeti Intézet archívumából való.
} 
ben, lehetőséget ad az egyetemek teljes kapacitással való müködtetésére is". (Miniszterhelyettesi értekezletre..., id. Kardos és Kornidesz, 1990, 211-214. o.)

A javaslatot ekkor is ellenállás fogadta. Az ellenzők a föiskolai képzés színvonalának fokozatos emelkedéséröl szóltak, ${ }^{2}$ különösen a pedagógiai és a módszertani tárgyak esetében; az adott korosztály (10-14 év) speciális igényeit is hangoztatták; de szerepet játszott a helyi párt- és állami vezetők ragaszkodása is az adott régió föiskoláihoz.

Az MSZMP Politikai Bizottsága 1959 januárjában egy általános iskolareform előkészítése érdekében 12 tagú bizottságot hozott létre. A munkát később a Minisztertanács vette át, és célul tüzte ki egy, az oktatás egészével foglalkozó törvény elkészitését. Az előkészités dokumentumaiban az egységes tanárképzés problémaköre nem került elö. A tervezés bizonytalanságára utal, hogy míg 1954-ben túlképzést prognosztizáltak 1957-re, addig 1959-ben a törvényt előkészítő alsó fokú oktatási albizottság jelentős szaktanár hiányt - 1870 fö - mutatott ki az általános iskolák felső tagozatán. „Fennáll az a tarthatatlan helyzet - írja a jelentés -, hogy az osztott felső tagozat szaktárgyi óráinak csak 57 százalékát látják el megfelelő szakos tanárok.” A tanulólétszám jelentős emelkedése miatt (ún. Ratkó gyerekek megszületése) a tanárszükséglet is növekszik. A tanárhiány 1962-68 között mintegy évi 3000 fö lesz és még 1971-ben is 1500 pedagógus hiányzik. A tapasztalatok szerint, az egyetemeken végző 532 tanár közül csak 270 ment iskolába tanítani. „Mindezek miatt szükséges az általános iskolai tanárképzés lehetőségeit tovább szélesíteni a pedagógiai főiskolákon." Tehát nincs szó egyetemi szintű egységes tanárképzésről, amit az 1961-es III. számú oktatási törvény sem említ meg.

A törvény egész szelleme kedvezett a föiskolai képzésnek. Ezt fejezte ki többek között a gyakorlat előtérbe állítása az elméleti oktatással szemben. Az egyetemek fejlesztése néhány évvel az 1956-os forradalom után, amelyben a hallgatóknak kezdeményező szerepük volt, nem lehetett kívánatos a politikai vezetés számára. Erre utalhatott a felsőfokú technikumok és felsőfokú szakiskolák preferálása, és az, hogy Nyíregyházán új tanárképző főiskola létesítettek (1962. május 28-i 11-es számú törvényerejü rendelettel). A föiskola létesítése a helyi érdekek megjelenését, illetve a politika hatását mutatja: 1962-ben az MSZMP PB Szabolcs megyei titkára Benkei András volt, aki 1963-tól 1980-ig belügyminiszterként szerepelt. Biszku Béla is szabolcsi származású volt, aki akkoriban Kádár János után a második ember volt. A helyi pártvezetők másutt is védték „főiskoláikat”, az egyetemekhez kevesebb közük lehetett.

Az egységes tanárképzés napirendre tüzésére ismét alkalmat adhatott volna az 1972-es átfogó oktatási párthatározat. Ez azonban ismét elmaradt; a probléma lé-

\footnotetext{
${ }^{2}$ 1958-ra olyan döntés született, amely szerint a felsőfokú tanítóképzés három éves, az óvónőképzés két éves lesz, és az utóbbi külön intézményben történik. Ezt rögzítette 1958 novemberében az 1958. évi 26. számú törvényerejü rendelet.
} 
tezéséről csupán bizonyos utalások szerepeltek a dokumentumokban. Így például a párthatározat előkészítését végző főbizottság 1971. július 15-i vázlatában szólt arról, hogy az általános iskolák felső tagozatán csak 73 százalékos a szaktanári ellátottság; új pedagógusképzési koncepcióra volna szükség. Ennek módját nem részletezi, de említi, hogy az ,általános iskolai és középiskolai tanárok képzésének közelítése" megoldandó feladat. (Az állami oktatás..., id. Kardos és Kornidesz, 1990, 614-624. o.)

A főbizottság összefoglaló jelentésében (1971. augusztus 24.) pedig a következő megállapítások szerepelnek: „A pedagógusképzés jelenlegi rendszere túlságosan szétaprózott. A külön folyó óvónő-, tanító-, általános iskolai tanár-, illetve középiskolai tanárképzés fokozatai mereven szétválnak. (Az oktatásügy felülvizsgálatát..., id. Kardos és Kornidesz, 1990, 644. o.) Ez pedig nem szerencsés. Az 1972-es oktatáspolitikai párthatározat közvetlenül nem említi az egységes tanárképzést. Csupán általánosságban szól a tanári munka színvonaláról és a képzés megfelelő mennyiségéről. Ugyanakkor kijelenti, hogy a „tanítóképző intézeteket, a tanárképző föiskolákhoz kell kapcsolni, és a bennük folyó képzést főiskolai jellegünek kell elismerni." (Az állami oktatás... id. Kardos és Kornidesz, 1990, 677. o.)

Az egységes tanárképzésre az 1972-es határozat sem tett utalást. Az 1985-ös oktatási törvény sem hozott megoldást, bár az MSZMP politikai bizottsága a felsőoktatás helyzetéről és fejlesztésének feladatairól szóló 1981. február 3-i határozata szólt arról, hogy „ki kell dolgozni az egyetemi szinten integrált egységes szaktanárképzés modelljét, majd kísérleti tapasztalatok alapján dönteni kell bevezetésükről.”

\section{Kitekintés}

Az egységes tanárképzés gondolata a szakmai elképzelések része maradt, különféle polémiák témája volt. Oktatási konferenciákon, az iskolafejlesztés távlati koncepciójának vitáin újra és újra előkerültek a támogató és ellenző érvek is. A hat- és a nyolcosztályos gimnáziumok alakulása 1987-től kezdődően szintén a tanárképzés egyetemi jellegének szélesítését igényelték. Lényeges fordulat a rendszerváltás után jelentkezett, amikor a tudományegyetemeken tanárképző intézetek, karok alakultak, majd egyes főiskolai szakok egyetemi szintủvé akkreditáltatták magukat; országos szinten pedig többé-kevésbé egységesítették a pedagógiai, pszichológiai oktatást (1997/111. Kormányrendelet); és - példát mutatva - az ELTE-hez kapcsolt föiskolai tanárképzés az egyetemi képzésbe integrálódott. A bolognai reform bevezetése a tanárképzést a mesterképzés szintjére emelte, ez önálló szakot jelent, amit a tanárképző föiskolák is elérhetnek, illetve elértek. Ezek a törekvések tehát nem a föiskolák megszüntetését, nem is a „cégtábla átfestését” kívánták, hanem az egyes fejlődő, erősödő, alkalmas főiskolák egyetemi jellegét, szintjét célozták meg. Ezek hasznos eredmények lehetnek. S természetesen a további vitáknak egy történészi kitekintés nem szabhat határt. 


\section{Irodalom}

A vallás- és közoktatásügyi miniszter elöterjesztése a Minisztertanácshoz a szakrendszerü tanításra alkalmas tanítók továbbképzéséről 1947. július 3. In: Kardos József - Kornidesz Mihály (szerk., 1990): Dokumentumok a magyar oktatáspolitika történetéből 19451972. I. kötet, Kossuth Kiadó, Budapest. 110-111.

Az alsó fokú oktatási bizottság javaslata az alsó fokú oktatási intézmények továbbfejlesztéséről. 1959. november. In: Kardos József - Kornidesz Mihály (szerk., 1990): Dokumentumok a magyar oktatáspolitika történetéböl 1945-1972. II. kötet, Kossuth Kiadó, Budapest. 363.

Az állami oktatás helyzete, problémái, fejlesztésének főbb irányai. (Az oktatásügy felülvizsgálatát végző főbizottság vázlattervezete a KB ülésre készülő anyag összeállításához. 1971. július 15.) In: Kardos József - Kornidesz Mihály (szerk.,1990): Dokumentumok a magyar oktatáspolitika történetéböl 1945-1972. II. kötet, Kossuth Kiadó, Budapest. 614-624., 677.

Az MDP KV agitációs és propaganda osztályának kiegészítő javaslata az egységes tanárképzés bevezetésével kapcsolatos OM-előterjesztéshez. 1954. március 2. In: Kardos József - Kornidesz Mihály (szerk.,1990): Dokumentumok a magyar oktatáspolitika történetéböl 1945-1972. II. kötet, Kossuth Kiadó, Budapest. 197-201.

Az MDP Politikai Bizottságának határozata az egységes tanárképzés bevezetéséröl. 1954. március 10. In: Kardos József - Kornidesz Mihály (szerk.,1990): Dokumentumok a magyar oktatáspolitika történetéböl 1945-1972. II. kötet, Kossuth Kiadó, Budapest. 202.

Az MDP Központi Vezetőségének határozata a pedagógusképzés egyes kérdéseiröl. 1954. július 23. In: Kardos József - Kornidesz Mihály (szerk., 1990): Dokumentumok a magyar oktatáspolitika történetéböl 1945-1972. II. kötet, Kossuth Kiadó, Budapest. 204-205.

Az oktatásügy felülvizsgálatát végző főbizottság jelentése az állami oktatás rendszeréről (a kritikai szakaszban készült elemzés) 1971. augusztus 3. In: Kardos József - Kornidesz Mihály (szerk., 1990): Dokumentumok a magyar oktatáspolitika történetéböl 19451972. II. kötet, Kossuth Kiadó, Budapest. 644.

Az Oktatásügyi Minisztérium javaslata az MDP Politikai Bizottságának az egységes tanárképzés bevezetésére. 1945. március 5. In: Kardos József - Kornidesz Mihály (szerk., 1990): Dokumentumok a magyar oktatáspolitika történetéböl 1945-1972. II. kötet, Kossuth Kiadó, Budapest. 191-196.

Miniszterhelyettesi értekezletre készített előterjesztés az egységes tanárképzés bevezetéséröl. 1957. május 23. In: Kardos József - Kornidesz Mihály (szerk., 1990): Dokumentumok a magyar oktatáspolitika történetéböl 1945-1972. II. kötet, Kossuth Kiadó, Budapest. 211-214. 